\title{
Ryssland och Finlands kriminalpolitik
}

\author{
Af Matti Laine ${ }^{l}$
}

\begin{abstract}
Finland was a Grand Duchy of the Russian Empire from 1809 to 1917. Some scholars (e.g., Nils Christie) have proposed that the very severe criminal policies that prevailed in Finland during most of the $20^{\text {th }}$ century were the result of Russian influence. Historical facts don't support this. Finland had a large autonomy and could maintain the Swedish legislation of 1734 and 1772. Finland was never "a Russian country". The de facto abolition of the death penalty in 1826 might be the only reform influenced by Russia. Other reforms and ideas came from Germany and Sweden. Finnish research has found two main reasons for the severe criminal policy. Finland remained very late as an agrarian country, much later than other Nordic countries, and when its modernization began, the criminal policy moved closer to other countries. The bitter civil war of 1918 and its aftermath have also had some influence.
\end{abstract}

I den finska kriminalpolitiska diskussionen och forskningen har frågan om varför vår kriminalpolitik åtminstone under 1900-talets sju första årtionden var strängare än i de andra nordiska länderna varit föremål för en hel del begrundande. Här har man framför allt hänvisat till det stora antalet făngar, som kriminologer i de andra nordiska länderna började förundra sig över senast på 1950-talet. Vissa finska kriminalpolitiker kunde ännu efter kriget hävda att fångtalen berodde på att Finland hade en större mängd brottslighet. Men då man gjorde tillräckligt högklassiga jämförelser visade det sig att detta inte stämde. Ofta har man även reflekterat över Rysslands eventuella inverkan; vi var trots allt ett storfurstendöme under detta imperium i mer än hundra år.

Denna tanke har ännu under 2000-talet förts fram också av den norske kriminologen Nils Christie. Vid bl.a. det europeiska kriminologmötet 2003 konstaterade han följande:

* Title in English: Russia and Criminal Policy in Finland. 
Traditionally, their (dvs. Finlands, ML) penal system was a Russian one. They sent many prisoners to Siberia, but had also a great prison population at home. Up to the 1960s they had several hundred prisoners per 100,000 inhabitants. They were Eastern European in their penal policy. ${ }^{2}$

Nils Christie berättar även att det enligt hans åsikt är en likadan upplevelse att bekanta sig med den ryska fångvården som det tidigare var att bekanta sig med den finska fångvården. På basis av detta inlägg och vissa andra för länge sedan förda diskussioner har jag fått den uppfattningen att Nils till stora delar här även har en taktisk synvinkel. I syfte att övertala vissa länder, bl.a. balterna, som tidigare låg inom Rysslands och Sovjetunionens inflytelsesfär att sänka sina fångtal, hänvisar han till Finland som ett exempel på hur det är möjligt att bli kvitt det "ryska" bestraffningssystemet med hjälp av en civiliserad elit. Nu är man emellertid tvungen att fråga sig om denna tanke om den finska kriminalpolitikens och straffrättens ryska bakgrund verkligen motsvarar historiska fakta. Hade vi en rysk bestraffningskultur ända från 1800-talet fram till Inkeri Anttilas, K.J. Långs och deras kompanjoners tid på 1960-talet? En liten historisk kommentar är här av nöden.

Det första tvivlet väcks av det faktum som Nils Christie själv pekat på: Det finska fångtalets ökning började först i slutet av 1800-talet och särskilt efter år 1918, dvs. i praktiken efter att Finland blivit självständigt. Skillnaden till de andra nordiska länderna uppstod således inte under det ryska väldets, dvs. autonomins, tid. Deporteringar till Sibirien förekom förstås, men de handlade oftast mera om att förmildra systemet: Nikolai I förkunnade år 1826 på begäran av de finska myndigheterna att han omvandlar samtliga dödsstraff till deportations- eller tvångsarbetsdomar. I Ryssland hade man börjat avstå från dödsstraffet redan under kejsarinnan Elisabeths tid på 1750-talet, och detta fortsatte under Katarina den storas tid till följd av bl.a. Cesare Beccarias inverkan. Nu är det viktigt att uppmärksamma att det finska fångtalet började öka först då deportationerna upphört, inte medan de pågick. Dessutom var deporteringar lika mycket allmän praxis i Västeuropa, vilket skeppningarna från England till Australien utgör ett exempel på. För Finlands del förmildrade deporteringarna sålunda bestraffningspolitiken, eftersom man delvis avstod från 1734 års stränga strafflag och därigenom också dödsstraff i fredstid. På denna punkt frigjorde vi oss något från Sverige: I Finland verkställdes den sista avrättningen i fredstid år 1825, medan detta i Sverige skedde år 1910. ${ }^{3}$ Det är möjligt att detta var den enda betydande "ryska inverkan" på den finska kriminalpolitiken.

Den viktigaste motinvändningen framkallas just av den tradition som lärs ut $\mathrm{i}$ våra skolor, universitet och även min egen läroanstalt. Enligt den bibehöll Finland i hög grad det svenska rättssystemet och den svenska rättstraditionen under 
det ryska väldet. Förtrycksåren ändrade inte denna grundläggande faktor på något sätt. Tankar, ideologier och praktiska tillämpningar inom rättsfilosofin, straffrätten och fångvården härstammade från alldeles andra ställen än Ryssland. Blivande professorer begav sig inte till Omsk för att studera straffrätt.

Den uppsaliensiska professorn Torkel Jansson (2002) har hänvisat till att författare av 1800-talets författningstexter var ytterst noggranna med att man vid revideringen av gamla lagar och förordningar använde ett så "svenskt" uttryckssätt som möjligt. ${ }^{4}$ De strävade efter att framhäva vilken rättstradition och rättskultur de representerade och värnade om. Även fennomanerna agerade på samma sätt. På gavelgruppen till Ständerhuset, som uppfördes under det ryska väldet, finner man årtalen 1734 och 1772 . Vissa menar att man rentav kan hävda att 1734 års lag i Finland bevarades i en ursprungligare form än i Sverige, och att Finland under den senare delen av autonomitiden var ett "mera svenskt" land än Sverige. Jansson hänvisar också till generalguvernör Bobrikov, som utmärkte sig för sina förryskningssträvanden och sedermera mördades. I ett av Bobrikovs uttalanden berättar han att det kändes som om han hade färdats genom ett främmande land då han gjorde en studieresa till Finland. Finland var allt annat än ett ryskt land under 1900-talets början.

Under autonomitiden spred sig de västerländska tankarna om fångvård även till Finland. Samtidigt lösgjorde sig Ryssland snarare från de nya tankarna. Vid t.ex. den internationella fångvårdskongressen i London år 1872 motsatte sig Rysslands representant, greve Sollohub, cellfängelsesystemet och konstaterade att det brutaliserar fången och gör honom till en ständig utmanare av sina förmän. Sollohub hänvisade också till det ryska samhällssystemet, som inte möjliggör ibruktagandet av cellfängelser åtminstone med avseende på långvariga fängelsestraff. ${ }^{5}$ Med största sannolikhet utgör den dåtida linjedragningen bakgrunden till att straffångarna i Ryssland ännu till denna dag till stora delar avtjänar sina domar i arbetskolonier som baserar sig på gemensam inkvartering. Det finns enbart ett fåtal cellfängelser. Fängelsesystemet som baserar sig på modellen med kolonier och arbetsläger uppstod således inte på bevåg av Lenin, Stalin eller det senare Sovjetunionen, utan har sitt ursprung i beslut som gjordes redan på 1800-talet. För ungefär fem år sedan gav den dåtida premiärministern Vladimir Putin order om ett omfattande byggprojekt för cellfängelser. De utgör de första på över 100 år.

Till Finland kom cellfängelserna inte i helt ren Philadelphia- eller Auburnform, men de kom i alla fall under det ryska väldets tid. Det första moderna cellfängelset blev färdigt i Tavastehus år 1871. De som planerade fängelset hade gjort studieresor till Tyskland och Sverige (inte Ryssland). Samtidigt spred sig 
även flera andra västerländska tankar till Finland. Då Sir Walter Crofton år 1860 publicerade boken "Success of the Irish Prison System and Supervision", där han presenterade framstegs- dvs. progressivsystemet för fångvård (det s.k. iriska fångvårdssystemet), räckte det bara några år innan Helsingfors Dagblad (14.1.1863) rekommenderade detta irländska system. De västerländska inflytelsernas snabba spridning påvisas av att Finland redan i 1866 års straffverkställighetsförordning uppdelade tukthusfångarna i fyra klasser i enlighet med progressivsystemet. I praktiken kunde systemet förverkligas endast $\mathrm{i}$ obetydlig grad, eftersom man saknade de nödvändiga byggnaderna, dvs. cellfängelser. Planerna vad emellertid stora, och de representerade inte någon "sträng rysk" kultur. Det nyligen utkomna omfattande historiska verket som anknyter till fångvården och Vasa fängelse innehåller följande sammanfattning (Muiluvuori 2014, 94):

Samtliga straffrättsliga reformer och fångvårdsreformer kom från väster, till en början från England, Förenta staterna, Frankrike och Sverige, senare allt mer också från Preussen, som vid sidan av Sverige blev Finlands främsta förebild. De tyska inflytelserna stärktes ännu mer än förut då talrika kunga- och furstendömen under Preussens ledning år 1871 slöt sig samman till Kejsardömet Tyskland. ${ }^{6}$

Varför var fångtalet då så högt under 1900-talet och kriminalpolitiken så sträng? Ilari Hannula har i sin avhandling (2004) fört fram de två viktigaste faktorerna. Den första är 1889 års strafflag (i kraft 1894) och den andra är inbördeskriget år 1918 och därpå följande atmosfär.

Den nya strafflagen skärpte framför allt domarna för stöldbrott, vilket snabbt syntes i fångtalet. Lagen baserade sig på den s.k. klassiska skolans tankar, varvid individuella förmildrande omständigheter tillmättes mindre uppmärksamhet. Men senare ledde den s.k. sociologiska skolans synsätt inte bara till att systemet uppmjukades, utan också till att det delvis blev ännu strängare under 1920- och 1930talen. Enligt Pertti Myhrberg (1978) utgjorde Sveriges och Tysklands strafflagar från år 1864 respektive 1871 förebilderna för 1889 års strafflag. ${ }^{8}$

De straffrättsliga ideologier som förknippades med den nya strafflagen eller reformerna som följde på år 1918 kom inte från Ryssland, utan blicken riktades åter mot Tyskland. Å andra sidan hade det varit något besynnerligt om inbördeskrigets vita segrare hade tagit modellen för sitt straffsystem från tsarernas och bolsjevikernas Ryssland. De centrala kriminalpolitiska opinionsbildarna under 1930-, 1940- och 1950-talen, straffrättsprofessorerna Bruno Salmiala och Brynolf Honkasalo, var starkt inriktade på Tyskland. Man kan rentav tala om nazistsym- 
patier. Salmiala var en central ledargestalt inom den extremhögra Fosterländska folkrörelsen (Isänmaallinen kansanliike, IKL) och riksdagsledamot.

Varför räckte det ända till 1970-talet före systemet reformerades? Knappast är den "ryska kulturen" heller här en central faktor, trots att vi satt hopkrupna intill Stalin och de andra Sovjetledarna och Paasikivi och Kekkonen regerade. Den enklaste förklaringen kan vara att vi allmänt taget släpade efter. Många näringsstrukturella förändringar och socialpolitiska reformer förverkligades årtionden, rentav intill 100 år, senare än i de andra nordiska länderna. Under en lång tid var vi ett mycket agrart samhälle. Mängden lantgårdar och små bybutiker ökade ännu under slutet av 1950-talet. I ett agrart samhälle utdömer man av hävd mycket stränga straff för många brott. När Finland sedan förändrades, skedde det med en skräll under ca 20 år. Näringsstrukturen förändrades, människor flyttade från landet till städer och Sverige. Sociologer har kallat denna skräll den "Stora Förändringen". Man har bedömt att den utgör en av de häftigaste strukturella förändringar som skett i västra Europa efter andra världskriget.

Fångtalets nedgång och förmildrandet av straffsystemet var alltså en del av det finska samhällets moderniseringsprocess. Det hade troligen skett oberoende av vilka personer som hörde till den s.k. kriminalpolitiska eliten. Självfallet kan deras verksamhet ha försnabbat processen. Det är också möjligt att denna process hade påbörjats tidigare om vi hade undgått 1918 års tragedi. I Ryssland fördröjdes denna process åtminstone 70 år på grund av det fenomen som vi kände vid namnet Sovjetunionen.

\section{Noter}

1. Överlärare i kriminologi och bestraffningens sociologi vid Brottspåföljdssektorns utbildningscentrum.

2. Christie Nils: Re-integrative Shaming of National States, i verket Aromaa, Kauko \& Nevala, Sami (eds.) Crime and Crime Control in an Integrating Europe. Plenary presentations held at the Third Annual Conference of the European Society of Criminology. HEUNI Publication series 44, Helsinki, (2004).

3. Avrättningarna i Finland under inbördeskriget och andra världskriget är ett kapitel för sig. Under åren 1939-1944 verkställdes endast ett dödsstraff där gärningsmannen var en civilperson och hade gjort sig skyldig till ett s.k. civilbrott.

4. Jansson, Torkel: Två stater - en kultur, i verket Suominen Tapani (red.): Sverige i fred, statsmannakonst eller opportunism: en antologi om 1812 års politik. Atlantis, Stockholm, (2002)

5. Pears, Edwin (ed.): Prisons and Reformatories at Home and Abroad. The Transactions of the International Penitentiary Congress. Longmans, Green and Co., London, (1872).

6. Muiluvuori, Jukka: Vaasan linna 1863-2013 ja suomalaista vankeinhoitoa 1700-luvulta nykyaikaan. Vaasan vankila ja Rikosseuraamuslaitos, (2014). 
7. Hannula, Ilari: Rikosoikeudellinen järjestelmä kriisissä. Tutkimus kansalaissodan ja 1930luvun alun kriisin vaikutuksista vankilukuun, rikoslainsäädäntöön ja oikeudenkäyttöön. (The criminal justice system in a time of crisis. A study of the impact of the 1918 Civil War and the crisis at the beginning of the 1930s on the prison population, criminal law and the administration of justice). Suomalaisen lakimiesyhdistyksen julkaisuja A-sarja, N:o 251. Helsinki, (2004).

8. Myhrberg, Pertti: Rikos- ja prosessioikeuden kehitys Suomessa. Suomen Lakimiesliiton Kustannus Oy, Helsinki, (1978). 